
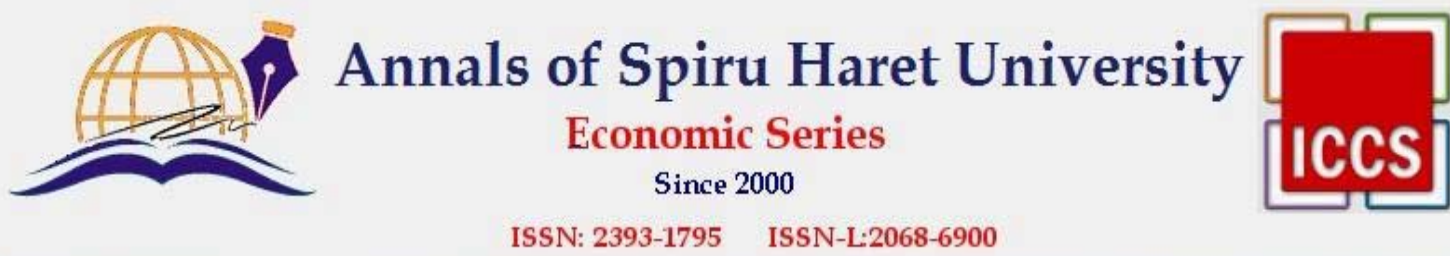

Issue 2/2016

\title{
CONSEQUENCES OF META-LINGUISTICS PARTICIPATION ON THE OPERATIONALIZATION OF DYNAMIC MANAGEMENT DOXASTIC LOGIC
}

Ioan I. GÂF-DEAC ${ }^{1}$, Cristina Monica VALECA ${ }^{2}$, Ioan GÂF-DEAC ${ }^{1,3}$, Elena GURGU ${ }^{1}$, Mihaela PÎRVULESC ${ }^{3}$, Ioana Andreea MARINESCU $^{1}$, Ion Iulian HURLOIU ${ }^{1}$

${ }^{1}$ Spiru Haret University, Ion Ghica Street, no. 13, Bucharest, 030045,

Romania, Tel.: +40214551000, Fax: +40213143900

${ }^{2}$ University of Pitesti, Targul din Vale Street, no. 1, Pitesti, 110040,

Romania, Tel.: +40348453102 Fax: +40348453123

${ }^{3}$ Bioterra University, Garlei Street, no. 81, Bucharest, 013722, Romania,

Tel.: +40214906129, Fax: +40212693438

Email: editurafmp@gmail.com,monica.valeca@nuclear.ro, ro_affairs@yahoo.com,elenagurgu@yahoo.com, m_pirvulescu@yahoo.com,

andreea_marinescu1975@yahoo.com, iulian.hurloiu@gmail.com

\begin{abstract}
The paper starts from the thesis that explaining the behavioural differences proves non-invasive, but the priorities of the operational existence of the company/entity/enterprise lead to invasiveness. There are no known doxastic programming ways/procedures/methods as long as managerial intervention may be assimilated to a hub in which the hypertext dominates/rules the common economic productive world. The identitary managerial phenomenon is far from fully meeting the attitudinal harmonization in the decision-making process. Doxastic management is an epistemological novelty covered by the scientific copyright in 2013 (Gâf-Deac, 2013). In the paper are described aspects about the procedural doxastic behaviour, the decisional doxastic situations in the tangible managerial field. Comparisons between the deterministic systems and the doxastic ones in the analysis of the managerial
\end{abstract}



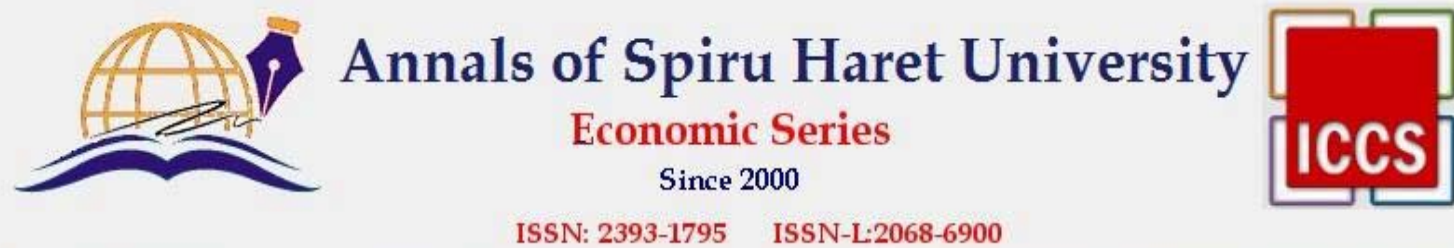

\section{Issue 2/2016}

phenomena are rendered and it is examined the participation of meta-linguistic to the operationalization of the dynamic doxastic logic in management. The doxastic managerial simplicity and the positive actional demarcation or limitation through doxastic management complete the research alignments.

Key words: doxastic management; doxastic procedural behaviour; decision-making; doxastic situations; meta-linguistic; doxastic management by logical dynamic.

JEL Classification: M10, M14, M20, M50

\section{Introduction}

Creating doxastic managerial structures, inducing doxastic networking/relationships/ relations and transforming doxastic alignments mean shaping the managerial meaning of essentialized actions of managers. Doxastic rewards quality is reflected in the amount of self-replicating responses of managers.

Contributory managerial accumulation generates direction and that of horizon determines only guidance. The obsessive challenge of proportionality between knowledge and lack of knowledge occasions the manifestation of societal unfulfillment elements.

Doxastic unhappiness is supported by the surplus of time, by the reconciliation with the delayed achievement. Therefore, redefining visions influences the managerial style. Reaching the border determines disinterest establishment among connectors empowered to complete organization and management.

Articulation process between organization and management anchors the realistic mimicry, the recognition of the un-altogether in open systems, such as the general managerial one. The distribution of the doxastic profiles is equivalent with the acquirement of the exhaustive knowledge in areas of multidimensional managerial performance.

The collision of conflicting lines in the decision-making process is considered the "mirror image" of stagnation, being bi-formulas of expressing the same realities addressed in its operationality. 

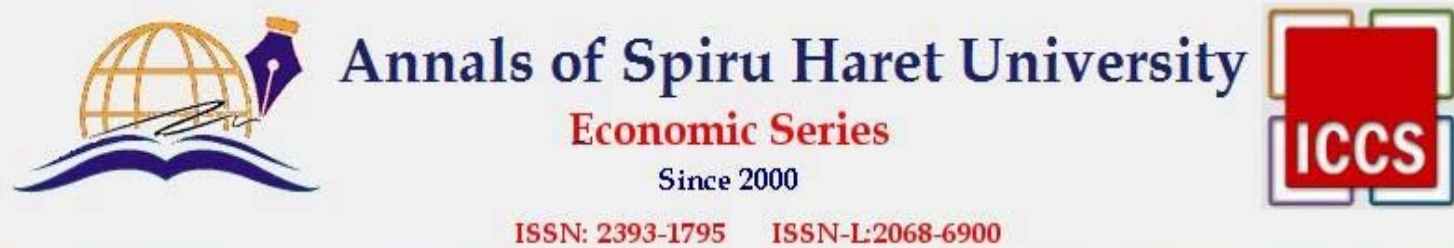

ISSN: 2393-1795 ISSN-L:2068-6900

Issue 2/2016

\section{Doxastic Procedural Behaviour}

General organization and management complexity requires the instauration of behaviour analysis.

Doxastic behaviour returns to the appreciative usage of the managerial epistemological determinations. General order of things and states exist in the real/virtual reality but research means examinative return to them.

Doxastic procedural behaviour outperforms the inability of rational uni-dimensional administration of the ordinary organization and management. In such a context it is glimpsed the manifestation of an intercultural behavioural communication, in which transdisciplinarity loosens up in the existing quasi-objective doxastic.

Essentially, the perception, at least the vague identification of this type of behaviour among managers, may be contributory to selfresponsibility. Manager secures an auto-belonging to the generational environment subjected to managerial capitalization.

In other words, a certain predestination/"conviction" to change is visible, to the extent in which in the pragmatic conceptual proximity medium, the environment in question can be accepted as multisectoral.

The true identities of the hypostasis registered by the manager in his production as "actor player" contributes to the formalization of the common ways of seeing the reality, which should provide the framework for a particular organization and management. [Gâf-Deac, 2011]

Explaining the behavioural differences proves invasive, but the priorities of the operational existence of the company/entity/enterprise lead to invasiveness.

There are no known doxastic programming ways/procedures/methods, as long as management intervention can be assimilated with a $h u b$ in which the hypertext dominates/ controls the common productive economic world. The managerial identitary phenomenon is far from fully meeting the attitudinal harmonization within the decision-making process.

The manager has the knowledge temptation from high, dominant positions, because of the illusion of co-participation in contextualization. [Gâf-Deac, 2008] 


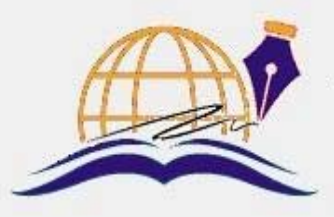

Annals of Spiru Haret University

Economic Series

Since 2000

ISSN: 2393-1795 ISSN-L:2068-6900

\section{Issue 2/2016}

It would be possible the existence of non-concentric circles in a scheme of managers' commonly divergent behaviour, whom are struggling with "entity's dysfunctions", on the one hand, and make advance efforts for development, on the other.

Peripheral management is re-centred towards essentiality by doxastic procedural behaviour (Figure 1). [Gâf-Deac, 2013]

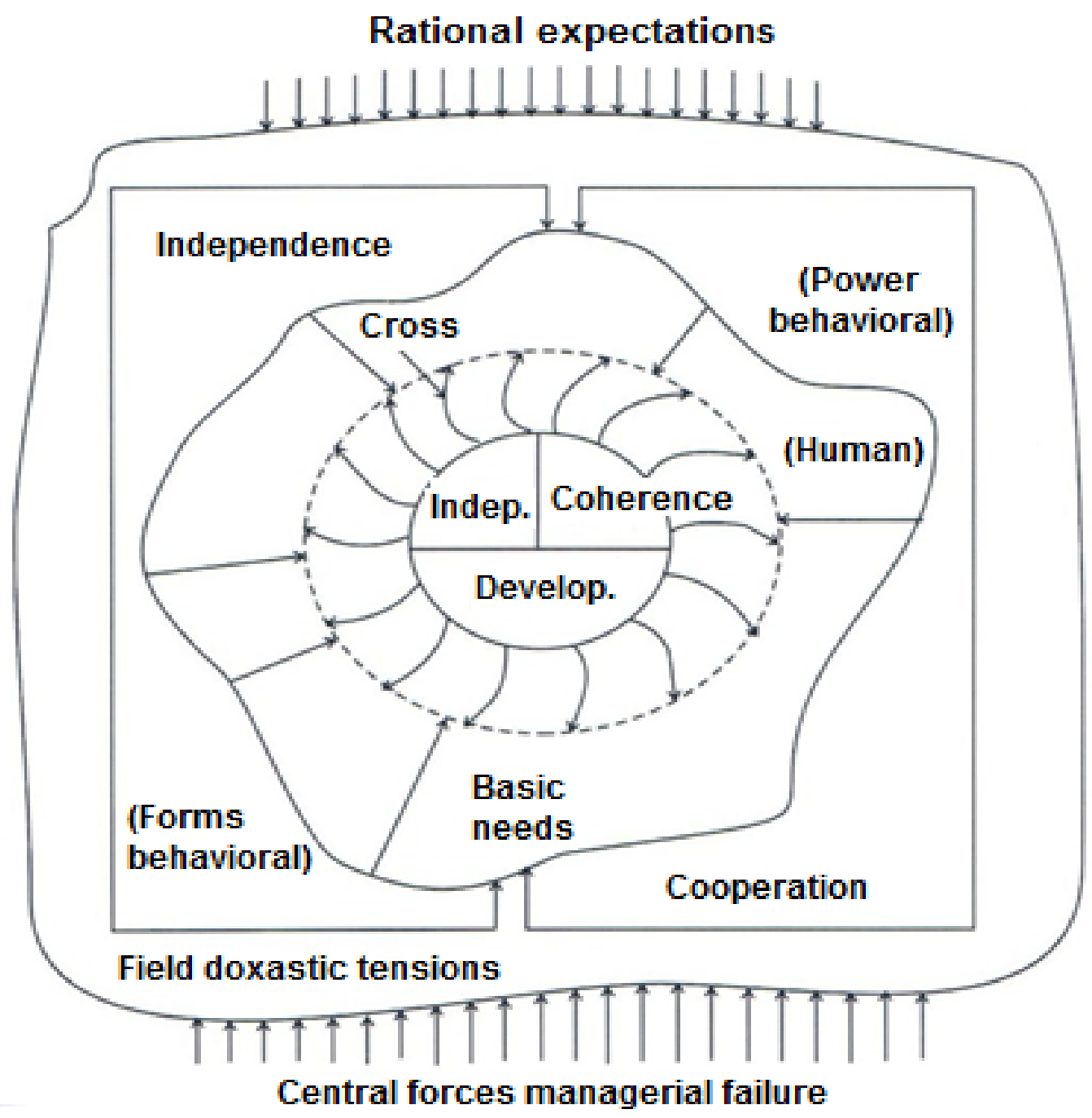

Figure no. 1. Focusing fundamental needs on human in the field of doxastic tensions

Source: Gâf-Deac, I., Bazele managementului doxastic, FMP, Bucureşti, 2013 

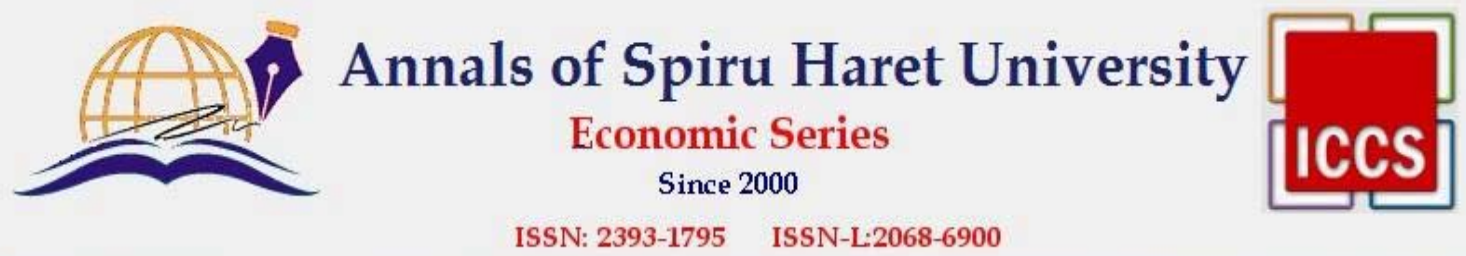

Issue $2 / 2016$

The new behavioural capability does not manifest in stable managerial spaces or in safe intervals of time.

As long as the struggle for managerial power is natural/conventional/normal, the respect for consumer of doxastic immateriality goes beyond organizational silence, respectively magnitude, unchained leadership.

Conventionally "bad" managerial behaviour distances from circulation the conventionally "good" doxastic managerial behaviour.

The behavioural side of the managerial applied field can be shaped in sectorial regime. Managerial "health" holistic stalls on the sectorial architecture of the organization and management general science (Figure 2). [Gâf-Deac, 2013]

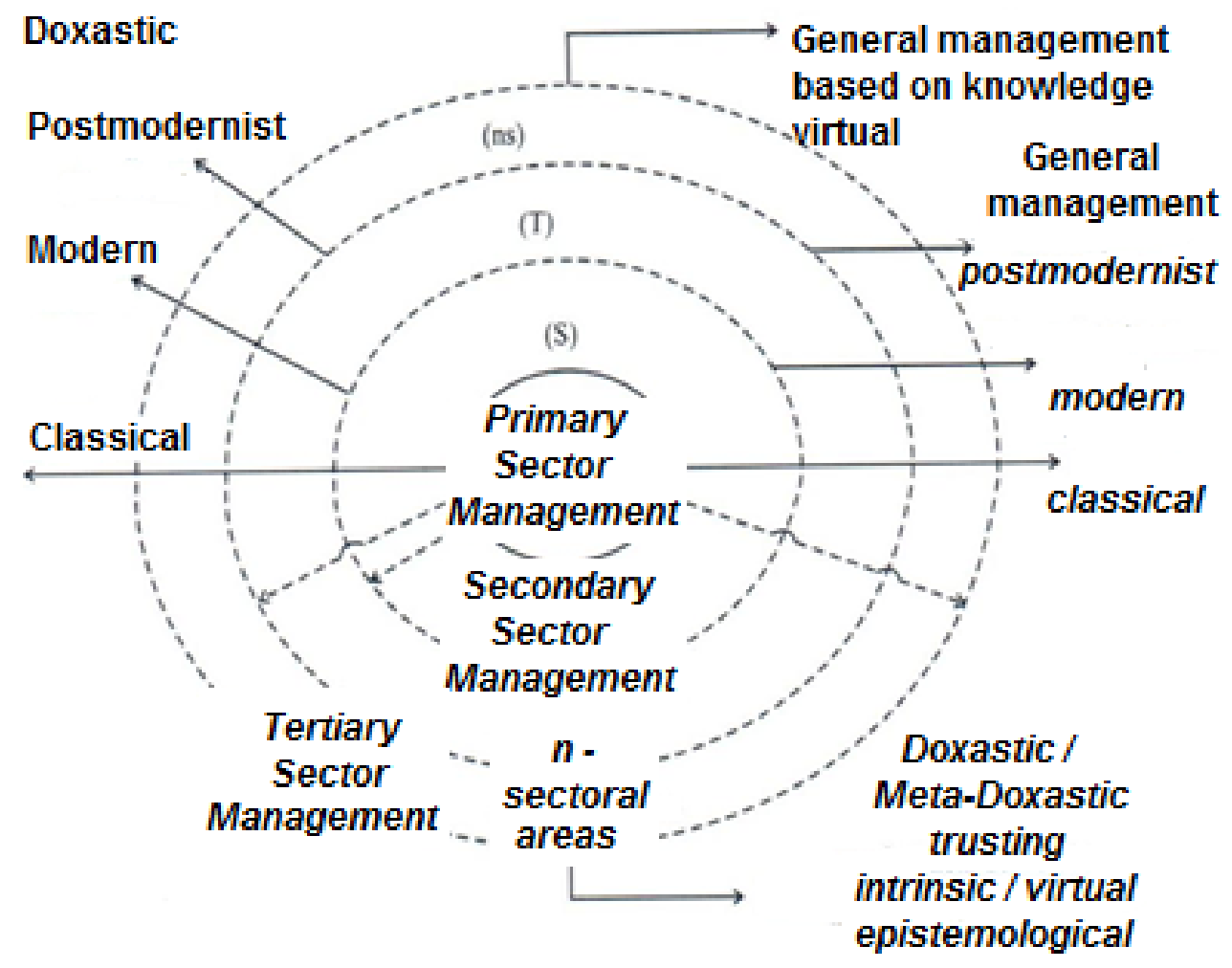

Figure no. 2. Sectorisation parallelism of the managerial contents with doxastic evolutions towards intrinsic/virtualized meta-doxastic

Source: Gâf-Deac, I., Bazele managementului doxastic, FMP, Bucureşti, 2013 

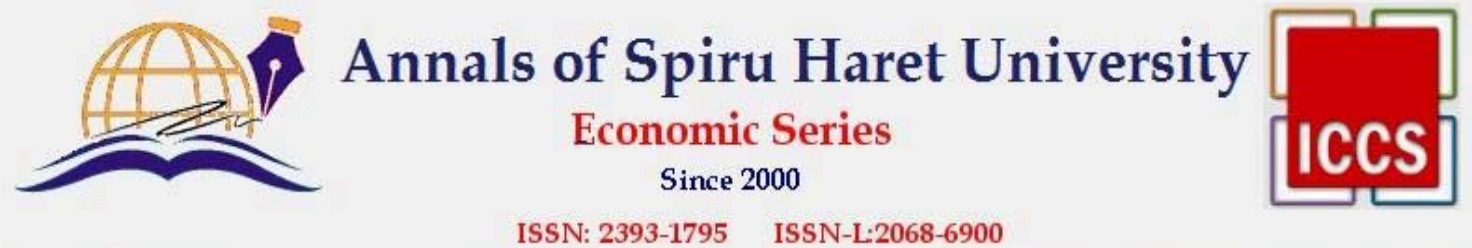

Issue 2/2016

In such a framework may be seen the "image of management", respectively may be noticed the "management as an image".

The actions and economies of the world are visibly under the incidence of management inherent/virtualized service playing the role of leading the "organization and management" and, simultaneously, of inducting towards the functional operationalization of the physical and knowledge resources. [Gâf-Deac, 2011]

We appreciate that the surrounding reality is extremely useful to advance the maximum of the virtualized managerial costs using the procedural doxastic behaviour (null as reflection in the conventional material costs), in order to achieve maximum of the conventionally targeted, glimpsed/imposed organizing and managing, through programming and planning.

In fact, the basis of such an intrusion into the concrete managerial operability comes from the indubitable asymmetry of uncertainty, observed in the complex mechanism of organization and management using doxastic as an osmotic ingredient in the procedural behaviour.

\section{Doxastic Decisional Situations in the Tangible Managerial Field}

A doxastic decisional situation is characterized by expressive reunion of three elements, namely:

1. Stimuli. The set of independent parameters or of stimuli (noted S) defines the set of objective conditions for trust in an organization and/or management, marking the uncontrollable variables. This category includes those elements of the managerial environment that cannot be modified when making a decision.

There are as well uncontrollable, common parameters, under the form of some restrictions. They can be continuous, discrete or categories of state.

2. Reactions. These are found in the set of possible rational alternatives (noted R), being used to answer every state of the objective conditions of the managerial trust and that make up the controllable variables. The set in question consists of all the possibilities that are available to the decision-maker for solving a decision within a horizon 

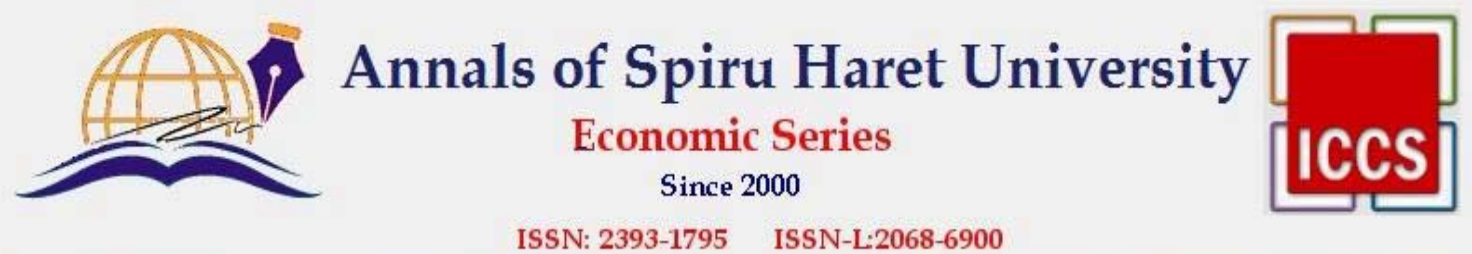

ISSN: 2393-1795 ISSN-L:2068-6900

Issue 2/2016

characterized by trust. As values, reactions are understood in the most general sense of the word "value" (quantity, size, type, number, etc). The set of reactions is generated by the set of stimuli from a state of the managerial nature.

3. Indicators. Are included in the set of outcome indicators (noted I) that can rationally be considered in choosing the decision criterion. In states of the given nature, for each variant of applicable rational managerial trust are obtained results that can be characterized by indicators.

Making a decision in situations from the doxastic environment means choosing a managerial action variant out of several possible, a thing done subordinated to the optimality requirement on/across borders in the area/horizon of conventionally favourable trust/custody.

Optimisation is always rendered by reference to a criterion.

An alternative is better than another only to the extent that it meets one criterion more than another in the managerial environment with imposed trust/custody. [Gâf-Deac, 2011]

The systematization of the decision criteria in doxastic context refers to:

1. Simple decision criterion; it is consider only one result indicator, the others being neglected or kept at a constant level (relative optimum).

2. Complex decision criteria; it is constituted a subset of the set of result I indicators, which is taken into consideration in solving a decision problem.

In case of the complex decision criteria several meta-managerial variants are distinguished [Gâf-Deac, 2013]:

a) limiting trust values are chosen for all result indicators derived from the subset of I, less one, depending on which max or min are optimized;

b) functional relationship between two or more indicators shall be established and combine into one;

c) we resort to transforming result indicators in deviations from optimum values 


\section{Issue 2/2016}

It sets a matrix A containing on rows the value of an indicator in each confidence variant and on columns the value of all indicators for a confidence variant:

\begin{tabular}{|l|l|l|l|l|l|}
\hline$V_{i}$ & $V_{1}$ & $V_{2}$ & $V_{3}$ & $\ldots$ & $V_{n}$ \\
$I_{i}$ & & & & & \\
\hline$I_{1}$ & $a_{11}$ & $a_{12}$ & $a_{13}$ & $\ldots$ & $a_{1 n}$ \\
\hline$I_{2}$ & $a_{21}$ & $a_{22}$ & $a_{23}$ & $\ldots$ & $a_{2 n}$ \\
\hline$I_{3}$ & $a_{31}$ & $a_{32}$ & $a_{33}$ & $\ldots$ & $a_{3 n}$ \\
\hline$\ldots$ & $\ldots$ & $\ldots$ & $\ldots$ & $a_{i j}$ & $\ldots$ \\
\hline$I_{m}$ & $a_{m 1}$ & $a_{m 2}$ & $a_{m 3}$ & $\ldots$ & $a_{m n}$ \\
\hline
\end{tabular}

Starting from the matrix of result indicators are calculated the elements of a transformed $\mathrm{C}$ matrix, with elements that constitute deviations from the optimum value of the resulted indicator:

\begin{tabular}{|l|l|l|l|l|l|}
\hline $\mathrm{V}_{\mathrm{i}}$ & $\mathrm{V}_{1}$ & $\mathrm{~V}_{2}$ & $\mathrm{~V}_{3}$ & $\ldots$ & $\mathrm{V}_{\mathrm{n}}$ \\
\hline $\mathrm{I}_{1}$ & $\mathrm{c}_{11}$ & $\mathrm{c}_{12}$ & $\mathrm{c}_{13}$ & $\ldots$ & $\mathrm{c}_{1 \mathrm{n}}$ \\
\hline $\mathrm{I}_{2}$ & $\mathrm{c}_{21}$ & $\mathrm{c}_{22}$ & $\mathrm{c}_{23}$ & $\ldots$ & $\mathrm{c}_{2 \mathrm{n}}$ \\
\hline $\mathrm{I}_{3}$ & $\mathrm{c}_{31}$ & $\mathrm{c}_{32}$ & $\mathrm{c}_{33}$ & $\ldots$ & $\mathrm{c}_{3 \mathrm{n}}$ \\
\hline$\ldots$ & $\ldots$ & $\ldots$ & $\ldots$ & $\mathrm{c}_{\mathrm{ij}}$ & $\ldots$ \\
\hline $\mathrm{I}_{\mathrm{m}}$ & $\mathrm{c}_{\mathrm{m} 1}$ & $\mathrm{c}_{\mathrm{m} 2}$ & $\mathrm{c}_{\mathrm{m} 3}$ & $\ldots$ & $\mathrm{c}_{\mathrm{mn}}$ \\
\hline$\sum \mathrm{c}_{\mathrm{ij}}$ & & & & & \\
\hline
\end{tabular}



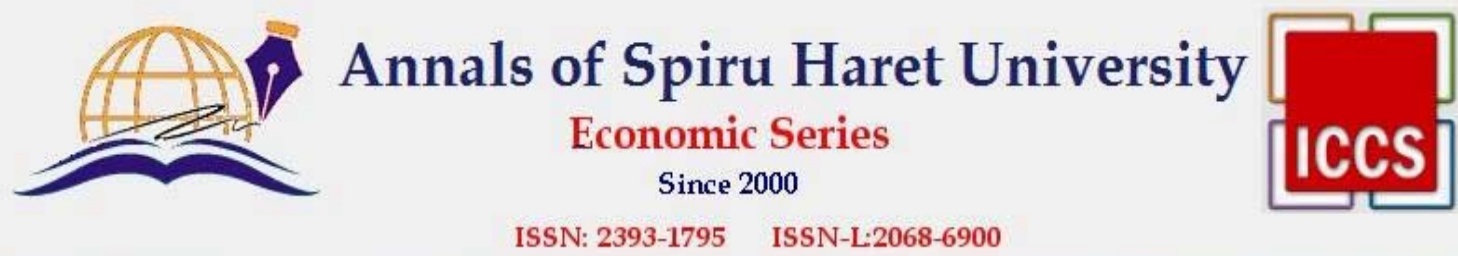

ISSN: 2393-1795 ISSN-L:2068-6900

Issue 2/2016

$\mathrm{c}_{\mathrm{ij}}$ elements are obtained using the ratio:

$$
c_{i j}=\xi \frac{a_{i x}-a_{i j}}{a_{i x}}
$$

in which:

with:

$$
\xi=\left\{\begin{array}{l}
+1 \text { for } \max . \text { (when it comes to } \max .) \\
-1 \text { for } \min . \text { (when it comes to } \min .)
\end{array}\right.
$$

$$
\begin{aligned}
& a_{i x}=\text { the optimal value of an indicator; } \\
& a_{i j}=\text { elements of A matrix. }
\end{aligned}
$$

The optimal variant is the one that has minimum the amount of $\mathrm{c}_{\mathrm{ij}}$ deviations:

$$
\text { The optimal variant }=\min \left[\Sigma \mathrm{c}_{\mathrm{ij}}\right] \quad \text { variant }
$$

Decision criterion is a measure by which variants are compared against each other, in order to choose the best alternative. [Gâf-Deac, 2014]

Decision-making means 1) choosing the decision criterion; 2) choosing the alternative of action (the decision itself). Simple decision criterion applies when reaching the objective can be characterized by a single result indicator - all the other results being ignored or considered insignificant for reaching the ultimate goal. In few cases the decision is adopted after a simple criterion. Frequently, we resort to a complex criterion, because it reflects more result indicators [Gâf-Deac, 2013]:

$$
\mathrm{D}=\mathrm{S} \cup \mathrm{R} \cup \mathrm{I}
$$

in which $\mathrm{D}=$ decision; $\mathrm{I}=$ set of result indicators (variables that reflect the results that would be obtained by adopting a set of $\mathrm{R}$ reactions in the objectives conditions defined by the S stimuli). 

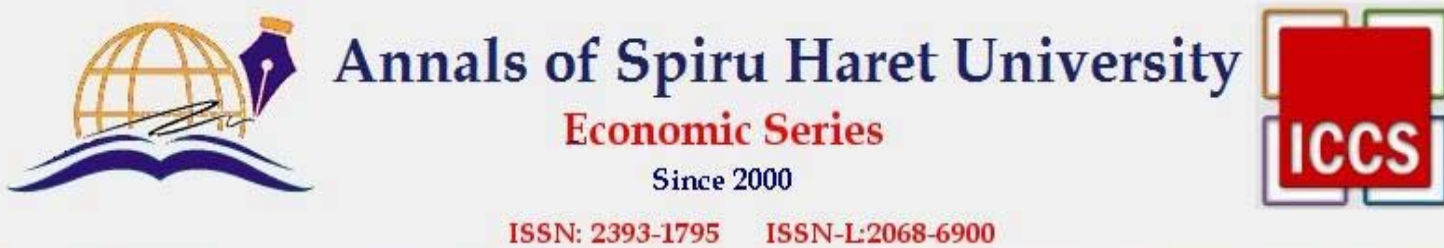

Issue 2/2016

Also:

$$
\mid \begin{aligned}
& \mathrm{I}=\left\{\mathrm{I}_{\mathrm{k}}\right\} \\
& \mathrm{I}=\mathrm{F}^{\mathrm{k}}(\mathrm{X}, \mathrm{Y}, \mathrm{Z})
\end{aligned}
$$

These result (response) variables are adopted functions of $\mathrm{R}$ and $\mathrm{S}$.

The ways of using a complex criterion refer to:

a) identification of a relationship between several result indicators;

b) limitation of the values a part of the result indicators can take part and maximization (minimization) after another indicator considered of prime importance (constrained optimization);

c) weighting the results by relevance or utility degrees.

A subset, that contains only indicators with utility grade $>0$ and $\neq 0$, is extracted from the I set of indicators. We search for a procedure to transform the results into a common measurement unit to be able to resort to their summing. In fact, the process described is based on the concept of "utility".

Comparisons between Deterministic and Doxastic Systems in the Analysis of Managerial Phenomena

A doxastic managerial phenomenon can be observed, but usually cannot be isolated from the real world. Laboratory managerial experience, thus the reproduction for research is not, usually, possible in the physical formulation. However, it appears that the processes and phenomena of organization and management unreels after their own laws, but do not prove to be completely repeatable or relatively stable and, in fact, non-random. The phenomena in management are, generally, observable and their measuring helps remove indeterminacy. Instead, the laws of economics can be described quantitatively by quantitative links. Statistics and mathematic accomplish economic quantitative representations. Different laws from other areas of the managerial science are found in similar actional formula in economy as well. Determinist model describes the functional links between uncontrolled (inputs) and controlled (output) elements of a system. [GâfDeac, 2008] 

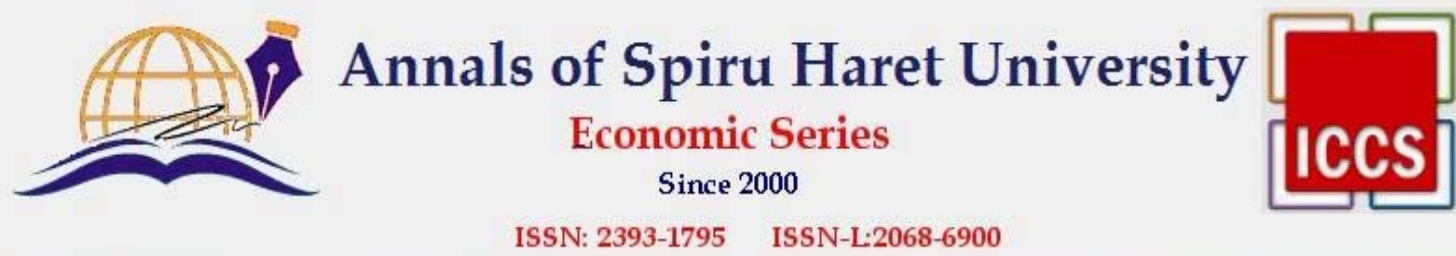

Issue 2/2016

Q notation is considered the symbol of an economic effect in a deterministic dependence (Figure 3).

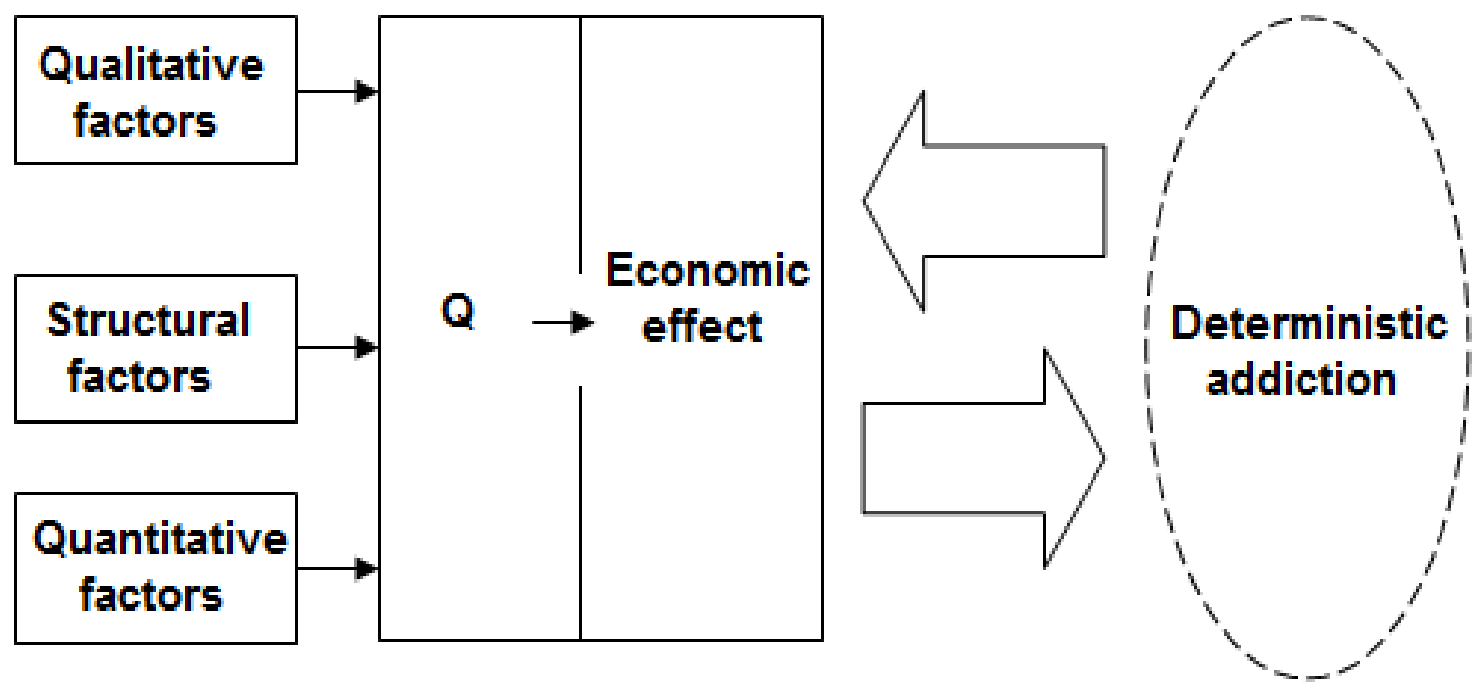

Figure no. 3. Expressing quantity in the system of deterministic managerial dependencies

Source: Gâf-Deac, M., Managementul afacerilor, Ed. FRM, Bucureşti, 2008

Deterministic models analyze the factors of space and time variation associated with the economic phenomena, including the managerial ones. [Gâf-Deac, 2008]

The general expression of the simple deterministic model is:

$$
\left\{\begin{array}{l}
y=f(x) \\
y=f\left(x_{1}, x_{2}, \ldots\right)
\end{array}\right.
$$

The managerial model describes the statistical and stochastic links between uncontrolled values (inputs) and controlled values (outputs) associated with the studied system.

Noting with $\mathrm{X}$ the influence factors and with $\mathrm{Y}$ the resulted variables, the managerial model has the form:

$$
Y=f(X)+U
$$



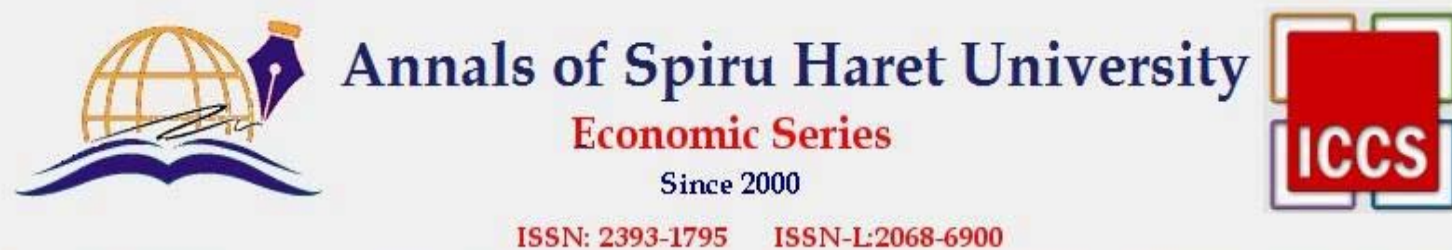

\section{Issue 2/2016}

If the formal description of the structure of the system is unapproachable we resort to the cybernetic formalizing vision.

Always a managerial model describes a regularity in the manifestation of a phenomenon of organization and management, but in the regulatory relationship is found at least one casual variable (U), respectively a random one (Figure 4.). [Gâf-Deac, 2013]

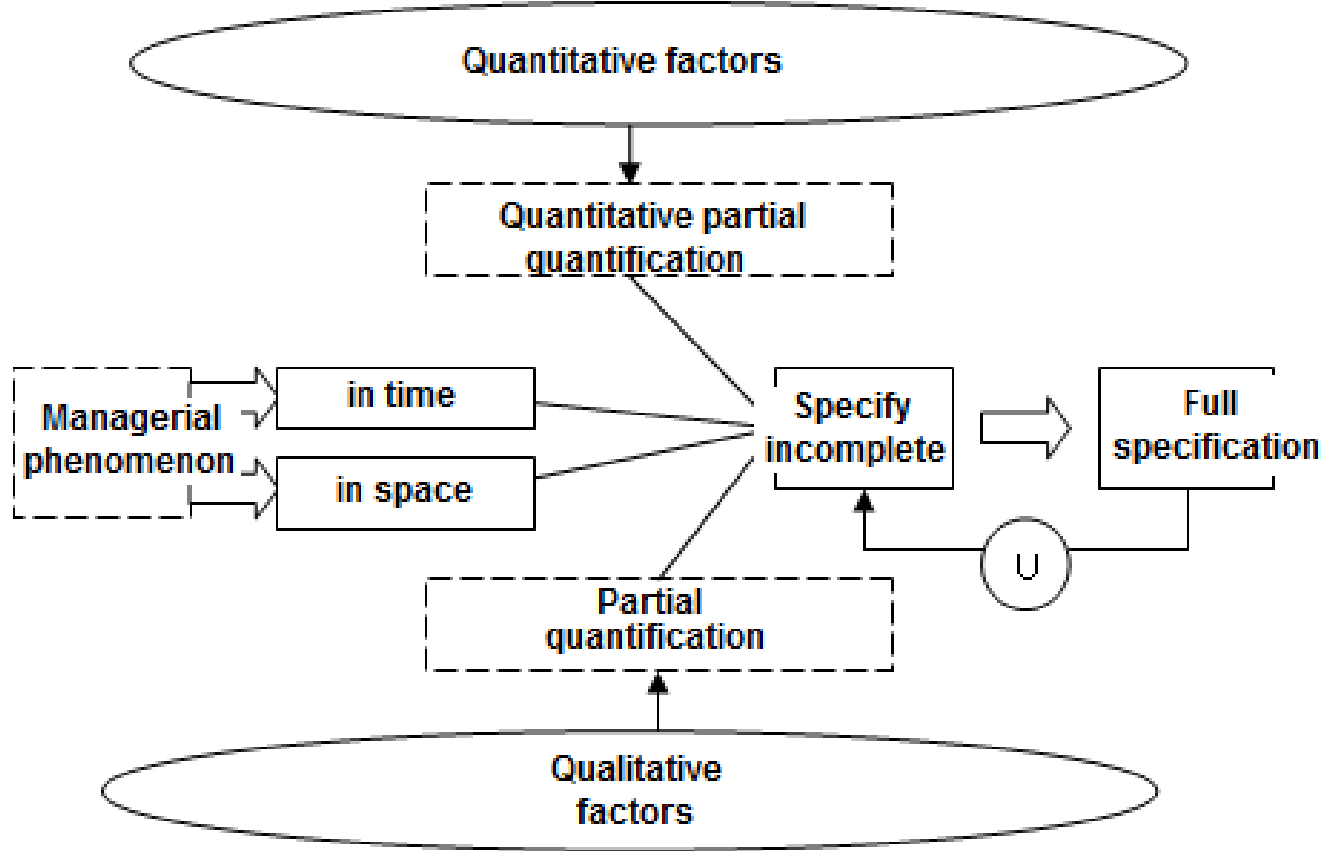

Figure no. 4. Introducing the casual variable (U) between the full and the incomplete specifications of the managerial model

Source: Gâf-Deac, I., Bazele managementului doxastic, FMP, Bucureşti, 2013

The casual variable does not contradict the quasi-stability of the managerial phenomenon manifestation or its quasi-repeatability, but it is recognized the need for the explicitness of the lawfulness of variation.

A motivation for introducing the casual variable in the managerial model derives from the impossibility of technically reproducing the phenomenon of organization and management (as lab source), but only based on observation, which incubates a certain amount of differentiation. [Gâf-Deac, 2004] 

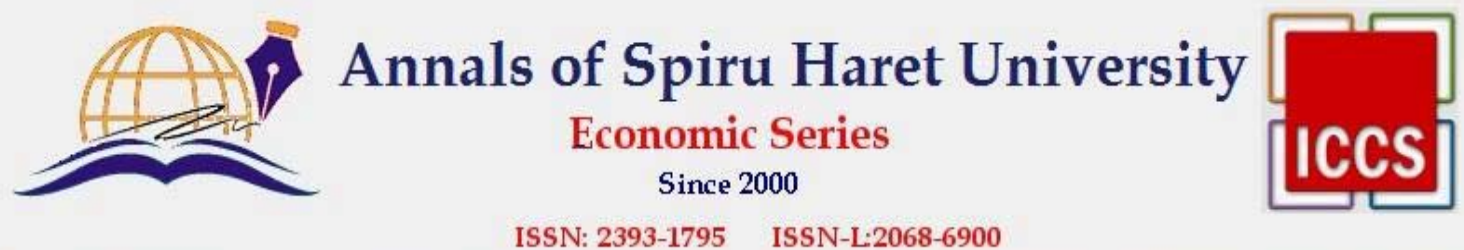

ISSN: 2393-1795 ISSN-L:2068-6900

Issue 2/2016

In a broader context, observations relating to organization and management are subject to selection and, as such, in chronological series particularities from the category of casual manifestations can be identified. Affections from the doxastic managerial models refer to the consideration of errors.

\section{Participation of Meta-Linguistic to the Operationalizing of the Dynamic Doxastic Logic in Management}

Combining elements of doxastic logic with the quasi-permanent revised formal theory of persuasion, in the area of management is obtained the manifestation of dynamic doxastic logic. This way are unified the logic alignments referring to the changes managerial conviction undergoes.

In the projection plan of a way to operationalize with the above conceptual elements, two approaches are foreseeable:

a) focusing manager's attention on the situations when a representation by language of an object or process of organization and management is affected by a modal operator changing (reviewing) the trust/conviction, when a particular defined and achieved image is widespread for use in all decision opportunities;

b) the adequacy of the managerial thinking to the image of "what it should be done", this operation being supported by non-material conditionalities.

Meta-linguistic participate effectively in narrated processes.

Managerial results are impossible to be fully and certainly known before their effective procurance. Therefore, accepting the managerial language revision means the wilful and operational simplification of the managerial conviction in relation to an object, process or phenomenon.

Studying the operators amending the managerial conviction starts from examining the dynamic version of the singular modal operator from the epistemic logic. If new semantic achievements formalize, associated with different states of managerial conviction/trust, their analysis is in the scope of "hyper-theories". The latter depicts relational situations by indicating the size of the differences between limitations or constraints, coming/arising from different states of conviction/trust. 

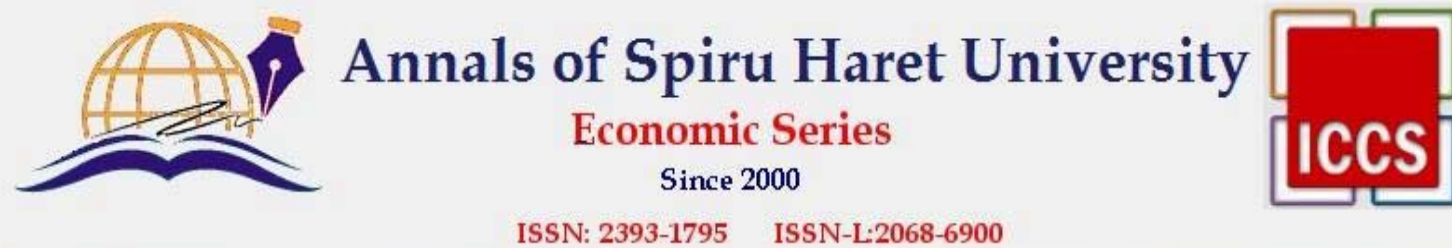

\section{Issue 2/2016}

The manager "backs way", "backs down", "limits himself", respectively "temperate himself" passing through various states of conviction/trust towards an object, process or phenomenon of organization and management. Corrective reactions (feedbacks) are accompanied by noncorrective reactions (fall-backs), which are encoded in semantic formulas.

Constraints, in their turn, are factually and representatively situated around the logic axioms or they are formalized under the requirements of some rules subsumed to the network/ logical framework associated with the organization and management. The structure of the managerial trust/conviction state lies, therefore, in the propositional and dispositional components.

\section{Doxastic Managerial Simplicity}

Doxastic management is not meant to generate new images of organization and management under an imperative more complex than that of the current managerial knowledge.

On the contrary, the new elements of knowledge regarding the organization and management passed through the managerial doxastic may be expressed simpler, more diverse.

Grecu, C. (1999) cited by Biriş, I. (2010) [Gâf-Deac, 2013] shows that "although apparently simple and unproblematic, the idea of simplicity reveals a multitude of sides and aspects initially unsuspected".

By extension, doxastic managerial simplicity returns from the organizational and managerial area logically (syntactically) characterized, from the one marked by generally experimental (semantic) alignments and from the situational pragmatic sphere of the general management (Figure $5)$.

The schematic approach pictured motivates the behaviour of those researching the organization and management, suggesting them the quasipermanent inclusion into the managerial observability flow. 


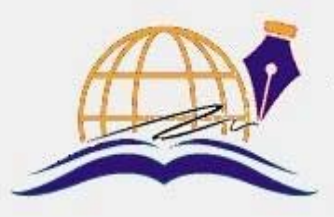

\section{Annals of Spiru Haret University}

Economic Series

Since 2000

ISSN: 2393-1795 ISSN-L:2068-6900

Issue 2/2016

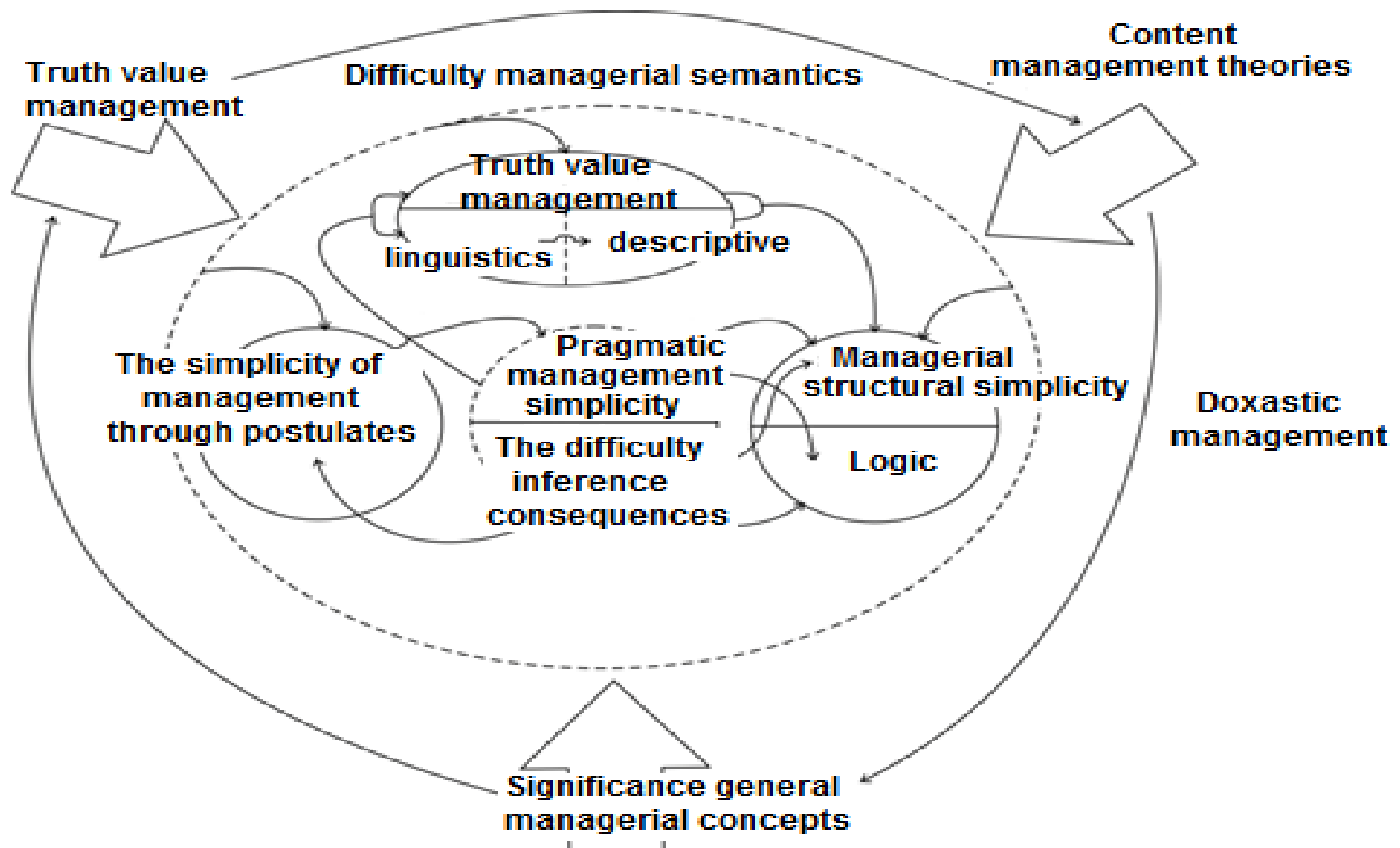

Figure no. 5. Examining the idea of doxastic managerial simplicity

Source: Gâf-Deac, I., Bazele managementului doxastic, FMP, Bucureşti, 2013

The doxastic side of examining the organization and management aims to reveal correlations, relationships, interrelationships and, generally, uniform, elementary aspects that are found beyond the borders of observability in the managerial facts.

The errors of organization and management in conventionalized sense come from the conceptual inadequacy of decisions to the real dependencies between management phenomena, processes and objects.

A managerial setup/configuration in a company is as a virtual area, but really delimited. As such, it is important to be able to define or extract a unity of such area. Instead, within the mentioned setup/configuration dependence, interdependence relationships, relations, conditioning, determinations etc. can be met. 

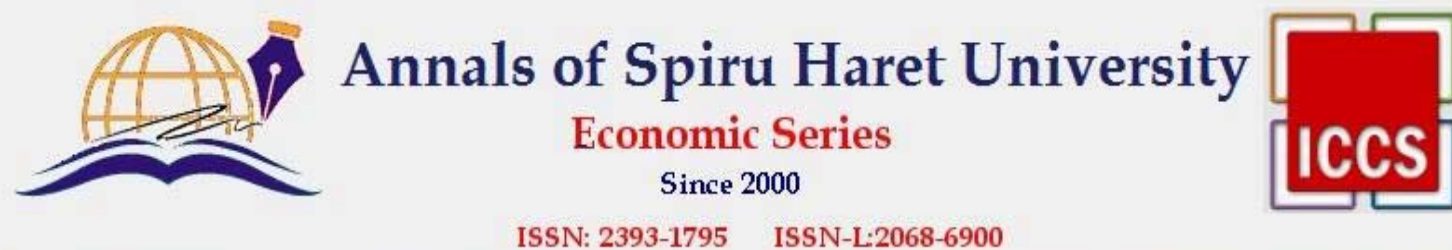

Issue 2/2016

Equally, it proves of real practical importance the extraction/highlighting of the relationships in question that mark the decisional construction.

If in management doxastic appeals to trust, assurance, self-induced persuasion etc. raised at the rank of parameters and valuations, it is also possible the extensive interpretation of the assertion referring to the doxastic managerial simplicity. According to Biriş, I. (2007) [Gâf-Deac, 2013], in such a type of process, one can contest the presence of the managerial sensations, considered preliminary psychological elements. That finding is triggered from J. Piaget's assessment that "what is initially given is a configuration, a whole to be explained".

Casuistic exemplification, by similarity for the considerations above, is that the examination of the organization and management from doxastic prospects does not mean firstly the perception of the infinitesimal elements (of the parts) of doxastic application of management, but the perception of the whole of the company becomes functional, operational, transformatively advancing on conventionally adequate organizational and managerial support, positively reactive to approaching targets, namely to their achievement.

So, doxastic management in simplified appearance is a form, an attribute of things of organization and management and/or a form selfdetermined by the essentialised management.

The perceptive consciousness of the manager immersively located in the organizational and management doxastic is marked by the managerial form, this being external to the self or the management as subject. Therefore, it is expected that organization and management to consist mostly/mainly of variables of the environment in which the firm works/lives.

The tentative of referencing the understanding of management, including the doxastic one, by reference to the mental peculiarities of the manager has been accepted (in general expression, for the most advanced sciences) at the beginning of the twentieth century. But nowadays, in our opinion, this understanding is the one that suggests a theory of psyche's dominance in action. In fact, we witness the unimaginable extension of the artificial intelligence hypertext using information technologies, clearly invasive, into modern man's subjective database. 

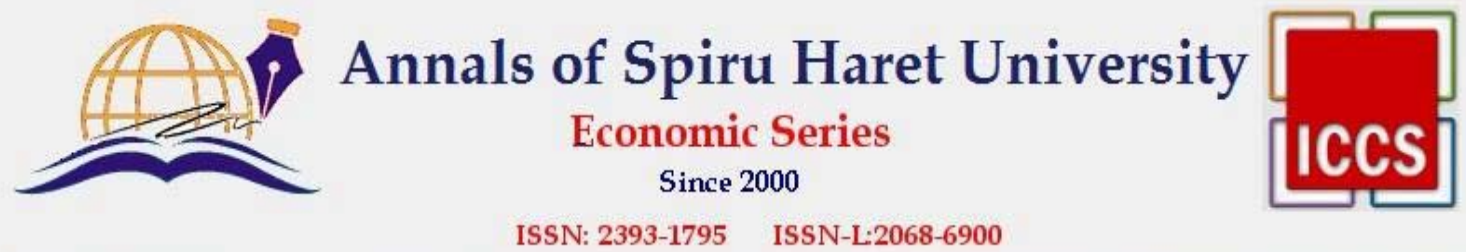

ISSN: 2393-1795 ISSN-L:2068-6900

Issue 2/2016

The manager from contemporaneity is separated/distanced from the effort of "memory", from the redundant storage of data, information, and elements of general/specific knowledge required by the processing for decisions. Therefore, understanding the science of management considered by us advanced science, is also possible without blocking the model elements of the world of phenomena, of sensations. Now the managerial persuasion comes from "objectified informational coldness" and not so much from the "subjective sensorial heat".

To ensure doxastic managerial simplicity it is necessary the construction of a logical system of the management concept. (Figure 6).

We consider that it is essential the inter-subjective construction, articulated with the successive reconstruction of the general management's basic objects. In fact, transitivity $(\Delta \mathrm{T})$ which marks the appearance of the assembly of subassemblies of objects and formal logical combinations of persuasive organization and management, covers the ascent from the base (extension) to the top (top management) in the Golden Triangle of classic management.

One can observe that the (n-1) floor exceeds the slopes of the legs of the triangle and, equally, the expanded size is also registered by the $\mathrm{n}$ floor as the last transitive operator of the managerial objects of the organized and managed entity. This excess is materialized by: 1) the substantival presence of doxastic among the members of the level subassembly or the manager; 2) the presence of the extensions of the artificial intelligence tools (collection, processing, storage and extra-logical usage of the knowledge about organization and management) and 3) the impossibility of the selfsufficient, singular behaviour of the top subassemblies from management, ultimately of the manager.

Originary start elements in the mentioned construction are communicable unitary experiences, respectively the unique managerial qualitative operations. In essence, those should be/remain unanalyzed. However, we feel that with the development of cognitive technologies, by piercing the windows strongly structured by knowledge is expected the reconsideration of the unanalyzability of the unitary managerial experiences. Being this way dismantled, they can be found relocated in the amount of common, ordinary, trivial configured units. Therefore, any element from the doxastic management is entitled to be classified as quasi-element. 

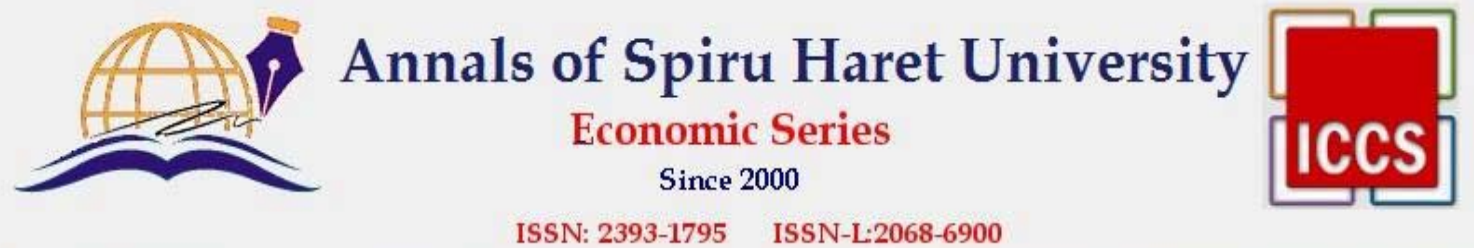

Issue 2/2016

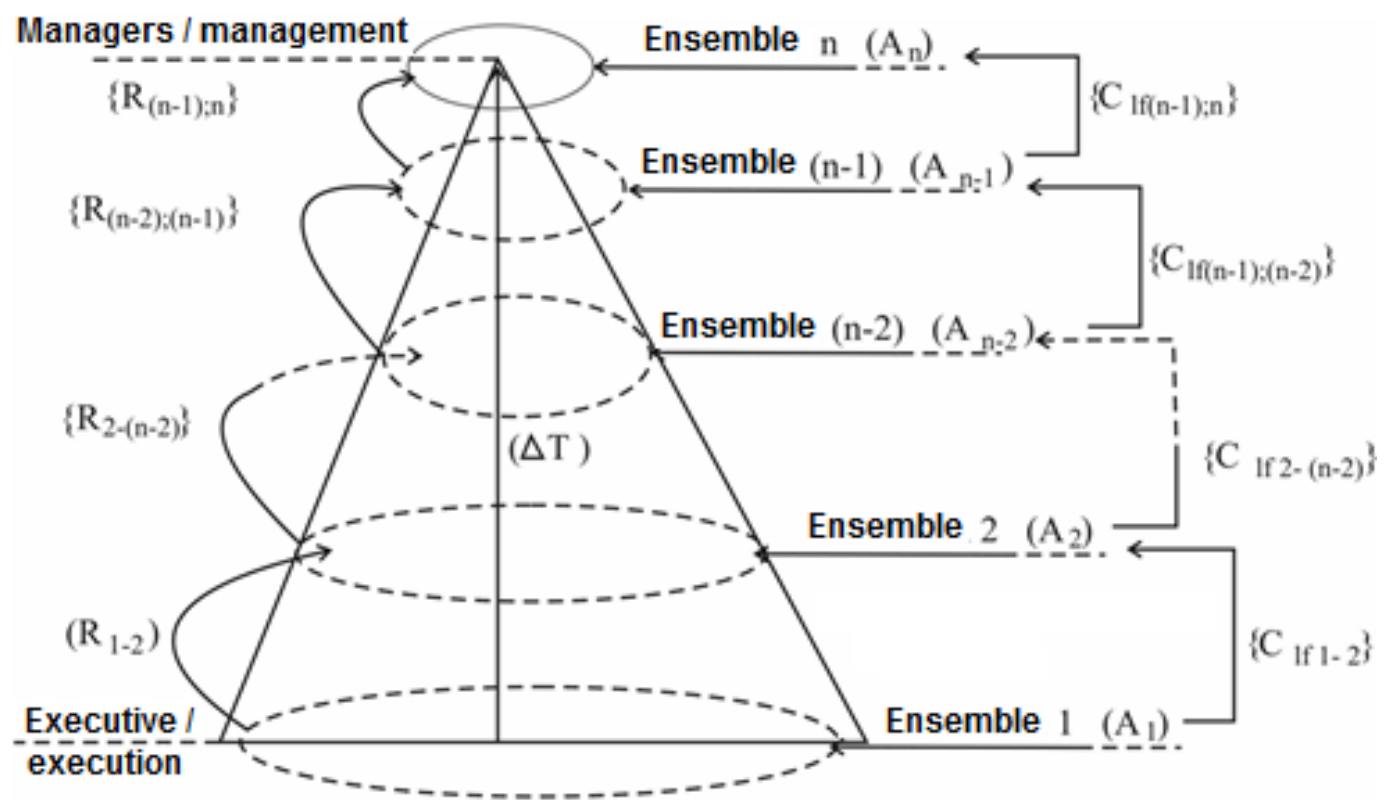

Figure no. 6. The foundation of the doxastic management concept's logical system using the assembly of subassemblies and formal logical combinations of organization and management

Source: Gâf-Deac, I., Bazele managementului doxastic, FMP, București, 2013

$(\Delta T)=$ transitivity; $\left\{R_{(n-1) ; n}\right\}=$ successive reconstructions of the basic objects of management; $\left\{C_{l f(n-1) ; n}\right\}=$ formal logical combination to build hetero-psychological managerial objects

On the other hand, a unified, communicable managerial experience can be separated only by reference to others/the others experiences of organization and management. In such a situation, the reference expresses the existence of the relations between originary, unitary, communicable and unique managerial experiences. These relationships can be symmetric when the resemblance is partial and asymmetric to void similarities. [Gâf-Deac, 2005]

The reconstruction of similarities represents the stake of the logical conceptual construction of doxastic management in order to obtain the trust/assurance that an organization and a management are strongly 

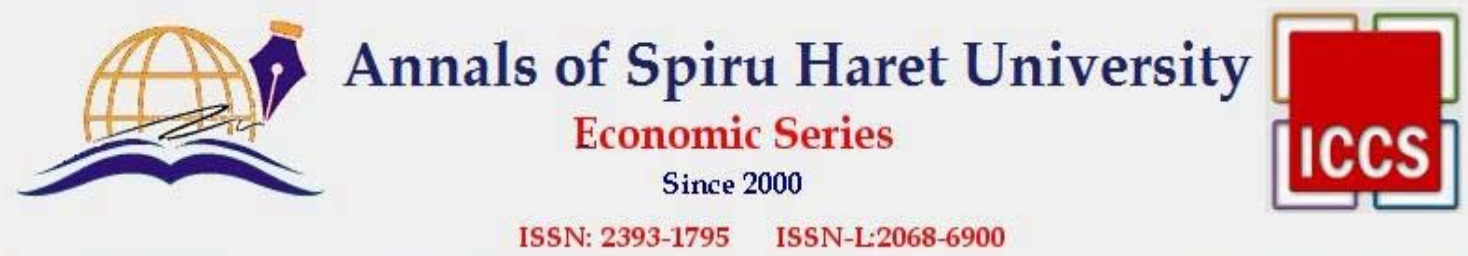

ISSN: 2393-1795 ISSN-L:2068-6900

Issue 2/2016

configured by the osmosis made compatible of the managerial organized, unitary, communicable and unique experiences. In our opinion, doxastic managerial simplicity is obtained from transitivity iterations/reiterations of the assembly of subassemblies on an ascending alignment of the logical and extra-logical forms of events of the type of the quasi-elementary, originary, unitary, unique and communicable experiences. Doxastic management becomes this way derivational.

A certain genealogy of the partial/total similarities and, simultaneously, of the non-similarities determines ascent forms of the organization and management. Avoiding the physicalistic formalization of doxastic management we assist, however, to the distancing from the means/procedures/techniques/methods etc. of materialization of the organization and management experiences.

The materialization requirement imposed in the above context refers to classical mathematical constructs inserted into the managerial phenomenology. It is, therefore, true the difficulty of engaging in the reminded intersession. But equally true, in the given situational context, is found our assumption that we need a new mathematics for the procedural mathematization of the doxastic management.

The new mathematics must be dis-symbolized, drained, cleaned of meanings, situation in which the scalar associative/transitive parameterization could re-include the organization and management in new types of re-objectified constructions, quantitatively resolved. Returning to quantity may be accompanied in the corresponding system of the management science through re-scaled circulation/processing of the organization and management events based on trust/assurance.

The scalar systematization of the managerial intuition based on managerial doxastic can be done in a new space, formally reconstituted to host quasi-elementary events of originary, unitary and communicable organization and management experiences. In fact, the phenomenalized space of the general management provides the observable conventional environment for the manifestation of the doxastic managerial simplicity. 

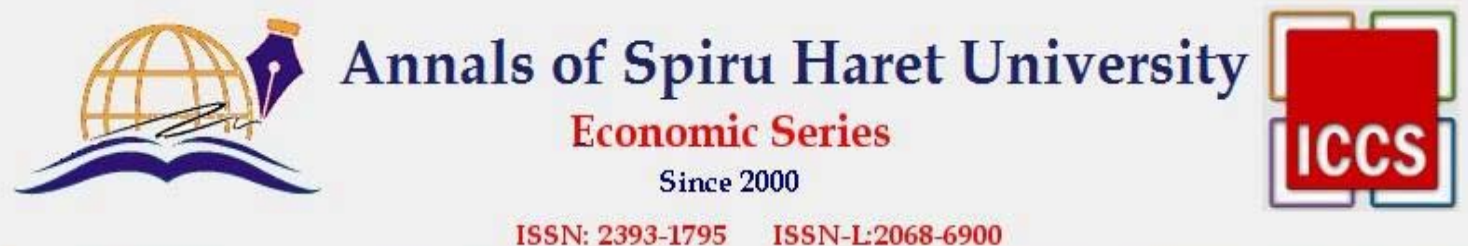

Issue $2 / 2016$

\section{Positive Actional Delimitation and Limitation Through Doxastic Management}

Management can be considered as a substance in a warehouse of thinking and ideas history throughout time targeting concerns among human community for production and reproduction. Management is an occupation for organization and leadership. [Gâf-Deac, 2012]

Kant shows that the whole philosophy can be reduced to three questions: a) what can I know? (metaphysical question); b) what should I do? (moral issue) and $c$ ) what can I hope for? (religious issue).

The above questions ultimately boil down to one: what is man? In a simplified, parallel and comparable plan, in management one can identify the following questions: 1) what can I know regarding the organization and management? (metaphysical character) 2) what should I organize and lead (organization and management's morality/ethics) and 3) what can I hope for regarding the organization and management (trust, conviction). The first two meanings $\{(1)$ and (2)\} are visibly met in the traditional management. The third question $\{(3)\}$ is quasi-evaded (or, indulgently, we can say that it has recorded "tangency") from managers' concerns. [Gâf-Deac, 2013]

In essence, in the reported context, for the first time the concept of doxastic management is introduced. Managers have the right to hope in connection to the organization and management's horizons. The psychogenesis of the doxastic managerial thinking should have the following starting points:

a. Managerial amazement. It is driven by the logic mechanism of thinking. This psychological resort causes inquiring onsets and meanings about the actions and activities of the people and systems for organizing and conducting the search/targeting search. In fact, managerial amazement is the source of organization and management problems. It is the faculty to generate meanings, assumptions or motivations to obtain answers regarding the organization and management. Managerial amazement is the quasiformalized interspace towards knowledge's horizons. From the disinterested operationalization of wonder we obtain the logos of the managerial substance. 

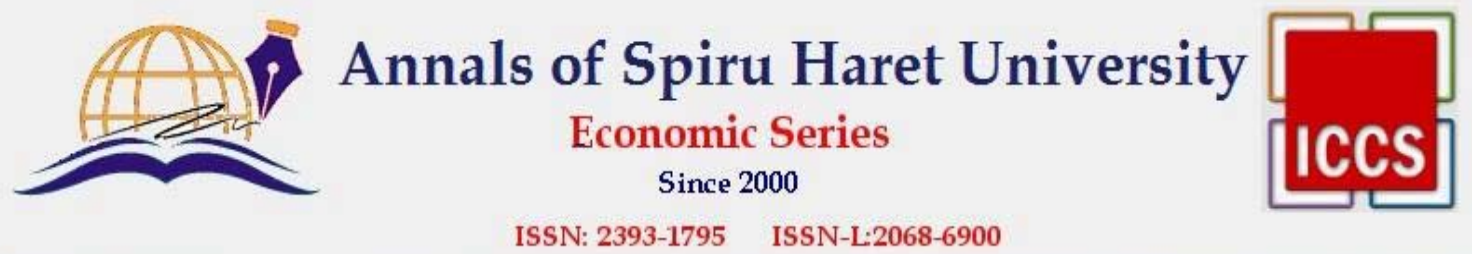

ISSN: 2393-1795 ISSN-L:2068-6900

Issue 2/2016

b. Managerial doubt. A manager does not trust his senses completely. All the more, he does not have the sense of auto-including knowledge in a field or another in order to formalize a certain type of organization and/or management. The feeling of appearance affects the socalled conviction on the reality of his managerial aspirations related objects. This paraphrase, occasioned by Descartes descriptions on doubt, is complemented by the following considerations: "doubt, in the usual sense of the word, is a feeling of oscillation, a mood that springs up alongside uncertainty". Yet, in the Cartesian sense, and by extension in the managerial understanding, doubt becomes a deliberate methodical posture, a precarious critical attitude. The manager is eager to eliminate the appearances/falsities and discover, according to Descartes, "a method for good orientation towards truth and to research the truth". Therefore, an important part of the managerial knowledge gained through the senses falls apart under the critical examination of reason.

It is state that the forms of managerial thinking belong to a specifically human structure and understanding, which in the manager position practice falls under the scope of contradictions or some irresolvable antinomies. The circumstances and manner of doubt crystallization among managers is in practice, whose reflection is on the pragmatic knowledge problem in the sphere of organization and management. [Gâf-Deac \& Roşca, 2014]

c. Managerial anguish. The flow of critical thinking caused by doubt extends the consequences on the manager by inducing the anxiety. It is the step towards the thinking crisis. The differences between what a manager knows and what he does not know are growing with the increasing of the general managerial knowledge and this desperate aspect of the "metaphysical anxiety" causes the so-called "anguish".

Jean-Paul Sartre has built a true dialectic for "angoisse", respectively for "absurd", pushing the appearance of their contents' horizons towards the last consequences which it might produce. In management, the overwhelming proportion of the finality of any anguish is the proximity/distance from fatality. [Gâf-Deac, 2013] 

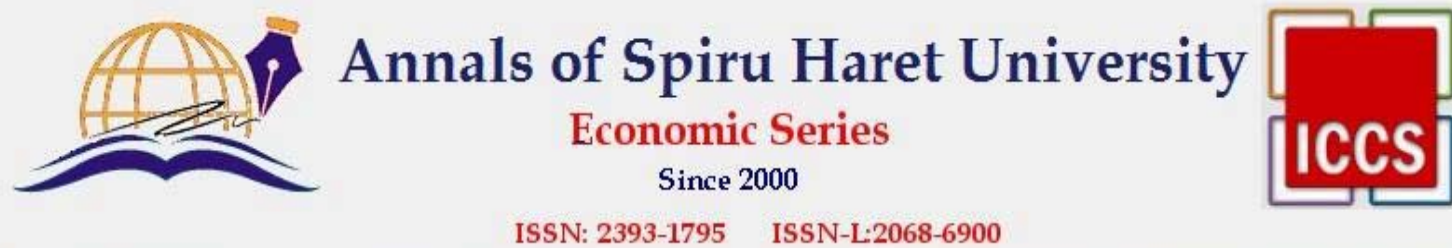

\section{Issue 2/2016}

Manager's image and condition is maintained by means of faith and hope that dismantle and annihilate contextual metaphysical inability to solve some problems of organization and management. It is the situation in which the path of the managerial existence and experience becomes assumed. Actional limitlessness becomes limitation for configuration. The stated starting points represent conjugated grounds for contributions to the definition of the doxastic management. Capturing and explaining the essential content of the doxastic management concept come from forms and criteria referring to nominality, essentiality, descriptivism and causality. The field of existence and manifestation of the general management is very broad, even with borderless dimensions, with difficult delimitation. [GâfDeac, 2007]

This is why, doxastic management is just a delimitation in the area of the all-embracing management. Any delimitation, however, is a limitation. This configuration, present in doxastic notions, marks a part of the general management's edifice. Knowing the substructures from the general managerial architecture determines the increase of the general theoretical and practical knowledge in an area or another.

The stated elements preceding a new state ask the manager answers to questions or problems. The manager must "say", "express himself" (i.e. "logos", according to the Greek meanings for old thinking). Managerial universe appears as subject to some fundamental laws and, as such, is coherent. Manager and management's usual coordinates are viewed (perceived) through the science of defining antagonisms.

Doxastic management determines metaphysical explorations for the object and the subject of organization and management. Through doxastic management it is intended the seeking and, accordingly, addressing the organization and management issues, before of their resolving.

Now it can be advanced the parallelism with the vision from philosophy (H. Bergson: “...il s'agit en philosophie, de trouver le probleme, et par consequent de la poser, plus encore que de la resoudre"). The true scientific spirit in general management is linked not so much to the positive and concrete achievements, but to the capacity to systematize, respectively to commit the transition from empirical knowledge of organization and management, dissipated to a true scientific knowledge. [Gâf-Deac, 2013]

Doxastic management paves the way for the managerial reproduction that goes beyond the immediate practical utility limits. On this 

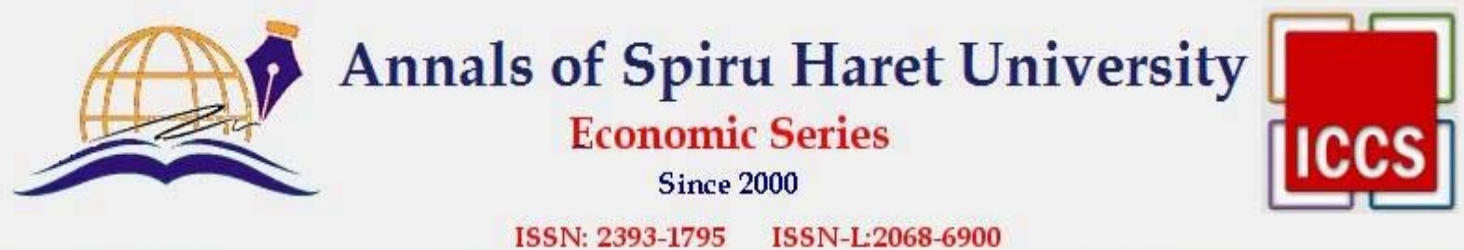

ISSN: 2393-1795 ISSN-L:2068-6900

Issue 2/2016

occasion it is sought the "substance of management". Limitlessness can, thus, become the source, respectively the origin, for general management's objects and subjects.

Doxastic management occasions the adaptation to future circumstances. Exploring the structures and relationships of organization and management provides clues for the becoming of the manager and the community he leads, all the evolutionary alignments arising from a specific law of contrasts that, despite their contradictory nature, can form harmony and unity.

Heraclitus considers that the antinomies need each other for their own existence. In the same way, in the general management, through its doxastic expression, without a previous difference, a present or future event of organization and management is unthinkable. [Gâf-Deac, 2013] The relativism of managerial knowledge met in contemporary, plus a certain metaphysic of the mobility professed by managers, justifies the birth of doxastic management. This sets in motion the quasi-static sequences which, paradoxically, tend and lead today to the dynamic logic.

The manager will have, through doxastic, a new commitment through a dynamic logic, more able to be consistent with the movements of a live managerial thinking. Thus, it will have the possibility to discover the contradictions and to overcome them. Through doxastic advance, each managerial synthesis will generate a new reality relative to its previous elements.

As such, doxastic management is the tool for imprinting/inducing the dynamism of becoming. The tool, and consequently, the method, by parallelism with what $H$. Bergson has proposed in lyrics, in management ends up to be considered the intuition.

There is a static managerial knowledge, a containment operated by manager's intelligence through neoclassical and modern managerial concepts. There is also a dynamic managerial knowledge, advancing at the same time with the reality, which is intuited in its future depth using doxastic visions. In this way we can say that the manager remains the expression of the human, and reality is becoming through organization and management. 


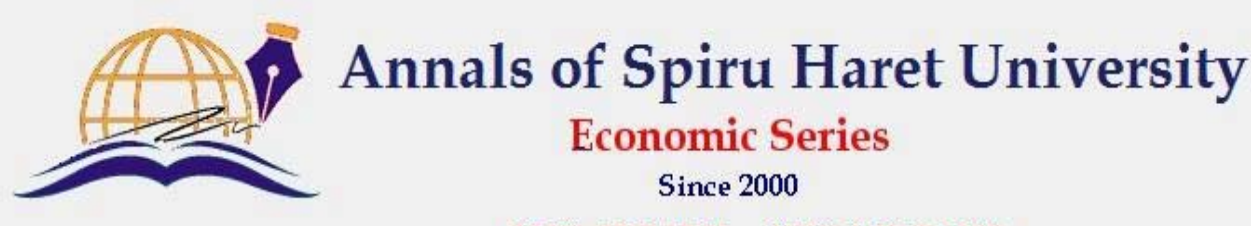

ISSN: 2393-1795 ISSN-L:2068-6900

\section{Issue 2/2016}

\section{Conclusions}

- Doxastic management can be the science of manager as manager, being incurred the conditions for extending the systematic managerial knowledge, of general nature. Using doxastic management, the general management turns its condition of contained science in that of comprehensive science. The attitudes of amazement and anguish contribute to building the theory (called by the Greeks "theoria").

- In contemporaneity we have come to decanting the permanent management of its global substances, which represents the so-called perennis management. The traditional view of management is about to be circumvented, eroded. Not so much the organization and management, but the path to organization and management is essentially retained by managers' attention. This new attitude offers prerequisites for interested/engaged managerial metaphysical concerns. If in philosophy are met the disinterested metaphysical concerns (focusing human's sight and mind towards encompassing the yet incomprehensible), in management, the principle of production and reproduction and the economic becoming appear as being "contained", once the road to comprehension (the road to organization and management) is discovered and covered.

- Doxastic managerial simplicity, in our view, is not in osmosis with the naturalized epistemology, out of which to be distinguished methodologically the knowledge elements based on the psychology of perception or on the physiology of senses. On the contrary, the doxastic represents the validation of the senses and perceptions in objectified windings, relatively independent of the hyper-textual penetrations from the phenomenal/ phenomenalized world of sensations.

- The mathematization of experience, including of the sensorial one, is another way of symbolized offer for modelling the informational cooling, respectively maximizing or minimizing the trends towards knowledge essentialities, for the implied, intrinsic and automatic, itself foundation of decision. The danger of manipulating the managerial world using symbols can be alleviated/eliminated by the parametric insertion into management of any sign of intentionality for doxastic organization and management. 

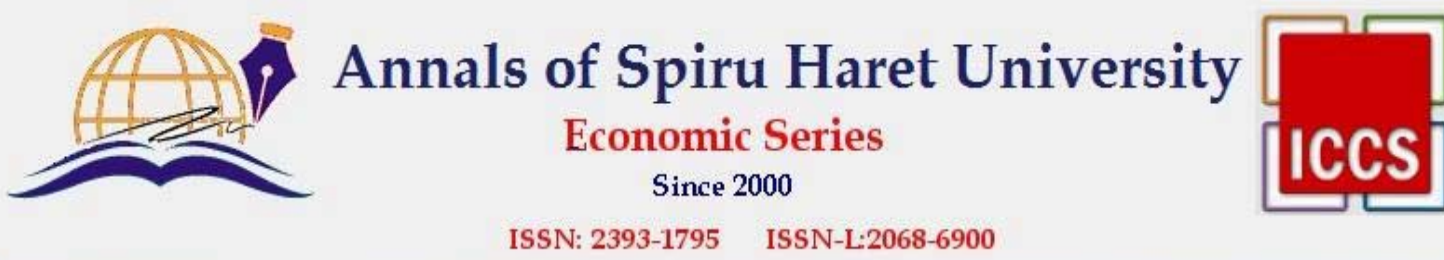

Issue 2/2016

\section{References}

1. "DEX online", https://dexonline.ro.

2. "Merriam-Webster Online Dictionary", http://www.merriam-webster.com.

3. "Online Etymology Dictionary", http://www.etymonline.com.

4. A. Vanditti, "Indeterminancy and Endogenous Fluctuations in Two-Sector Growth Models with Externalities", Universite Aix Marseille III (1996).

5. D.J. Watts, Small World (New Jessey: Ablex Norwood, 1989).

6. I. Gâf-Deac, Bazele managementului doxastic (Bucureşti: Editura Fundației România de Mâine, 2013).

7. M. Cozic, Logical Omniscience and Rational Choise, Department of Philosophy (Sorbonne, Paris, 2004).

8. M. Gâf-Deac and I.P. Roșca, Particularități regionale ale gestiunii corporative in România (Chișinău: Editura ULIM, 2014).

9. M. Gâf-Deac, Bazele practicii manageriale (Deva: Editura Infomin, 2011).

10. M. Gâf-Deac, Management corporativ (București: Editura Fundaţiei România de Mâine, 2014).

11. M. Gâf-Deac, Management general pentru economia bazată pe cunoaştere. Aplicații în sistemele productive operaționale (Deva: Editura Infomin, 2011).

12. M. Gâf-Deac, Management general. Teorie şi aplicații (Bucureşti: Editura Fundației România de Mâine, 2008).

13. M. Gâf-Deac, Management general. Teorie şi practică (București: Editura Fundației România de Mâine, 2007).

14. M. Gâf-Deac, Management modern. Elemente de bază şi studii de caz (Bucureşti: Editura Fundației România de Mâine, 2005).

15. M. Gâf-Deac, Management operațional (Deva: Editura Infomin, 2011).

16. M. Gâf-Deac, Management. Baze generale şi legislative (Bucureşti: Editura Fundației România de Mâine, 2003).

17. M. Gâf-Deac, Managementul afacerilor (Bucureşti: Editura Fundaţiei România de Mâine, 2008).

18. M. Gâf-Deac, Managementul modelării structurilor tehnologice (Deva: Editura Infomin, 2002).

19. M. Gâf-Deac, Managementul producției (București: Editura Fundației România de Mâine, 2008).

20. M. Gâf-Deac, Teoria deciziei (Bucureşti: Editura Fundației România de Mâine, 2004).

21. M. Kocken, The Small-World (New Jersey: Ablex Norwood, 1989). 


\section{Issue 2/2016}

22. R. Audi and M. Setup, Doxastic Voluntarism and the Ethics of Belief (Oxford:

Ed. NY, 2001).

23. R. Audi, "The Ethics of Belief. Doxastic Self-Control and Intellectual Virtue", Syntheses, no. 161 (2008).

24. R. Audi, Conceptele ştiinței (Bucureşti: Editura Academiei Române, 2010).

25. R. Carnap, Semnificație şi necesitate (Cluj Napoca: Editura Dacia, 1972). 